\title{
Are Disasters a Risk to Regional Fiscal Balance? Evidence from Indonesia
}

\author{
Astrid Wiyanti $^{1,2} \cdot$ Alin Halimatussadiah ${ }^{3}$
}

Accepted: 22 September 2021 / Published online: 10 November 2021

(C) The Author(s) 2021

\begin{abstract}
Indonesia is an archipelago country and is fairly vulnerable to disasters. While disasters generally affect government revenue and expenditure, their effects likely vary by country. This study examines the effect of disasters on the fiscal balance, revenue, and expenditure of local governments. We used panel data and fixed effects methods to estimate the degree to which disaster severity influences budgetary solvency at the district and provincial levels in Indonesia between 2010 and 2018. This study revealed that disasters can strain fiscal balance at the district and provincial levels due to a decrease in own-source revenue and an increase in social assistance expenditure, capital expenditure, consumption expenditure, and unexpected expenditure. The district expenditure most threatened by disasters is consumption expenditure, while the provincial expenditure most threatened is unexpected expenditure. We also found that an increase in capital expenditure can lead to financial burden due to delays of planned projects or post-disaster reconstruction. Based on these findings, it is clear that some forms of insurance or other financing schemes are necessary to mitigate the adverse impacts of disasters on regional fiscal balance.
\end{abstract}

Astrid Wiyanti

astrid.wiyanti@kemenkeu.go.id; astrid.wiyanti@ui.ac.id

1 Economic Planning and Development Policy, University of Indonesia, Jakarta 10440, Indonesia

2 Center for Climate Finance and Multilateral Policy, Fiscal Policy Agency, Ministry of Finance of Indonesia, Jakarta 10710, Indonesia

3 Department of Economics, University of Indonesia, Depok 16424, Indonesia
Keywords Budgetary solvency $\cdot$ Disaster impacts - Disaster insurance - Fiscal balance $\cdot$ Indonesia $\cdot$ Local government budgets

\section{Introduction}

The impacts of disasters, such as human fatalities, infrastructure damage, and welfare losses, tend to affect macroeconomic and fiscal conditions. Shabnam (2014), Bergholt and Lujala (2012), and Wu et al. (2018) all found that disasters impact economic growth. Disasters also pose a risk to state revenues and expenditures (Lis and Nickel 2010; Lee et al. 2018; Medina 2018). Disasters often result in increased emergency response expenditure, capital expenditure for reconstruction, and social assistance expenditure. They also tend to result in reduced productivity and individual income, leading to a decline in government revenues.

The effect of disasters on government revenues and expenditures varies by country. Klomp and Valckx (2014) found that the impact of disasters on a country's fiscal conditions is inversely related to its level of development. Miao et al. (2018), looking at the United States, found that disasters have no effect on government revenues or operational expenditure but negatively impact capital expenditure. Lee et al. (2018) found that disasters lead to decreased revenues and increased expenditures for governments in least-developed countries (LDCs).

This study examined the effect of disasters on the fiscal balance, revenue, and expenditure of local governments, using Indonesia as an example, in order to fill gaps in the literature. First, this study used disaggregated data at the district and provincial levels. Similar studies have largely been conducted at the national level (Lis and Nickel 2010; 
Noy and Nualsri 2011; Lee et al. 2018; Ouattara et al. 2018; Benali et al. 2019). Such studies generally consider total expenditure without distinguishing between each type of expenditure. As a result, government expenditure that is less or not affected by disasters, such as some employee expenditure, is included in this study's estimation model. Second, this study considered all disasters, regardless of the size of their impact. Third, this study used fiscal balance indicators to determine fiscal health in the regions.

Studies about the fiscal effects of disasters at the state level have been conducted by Miao et al. (2018) and Unterberger (2017). Miao et al. (2018) used disaggregated, state-level data from the United States, although the United States and Indonesia differ in many ways in their approach to revenue generation. For example, Indonesia uses value added tax, which is collected by the central government, but the United States uses sales tax, which is collected by state governments. Unterberger (2017) conducted research specifically on flooding, so further studies must be done to examine the fiscal effects of disasters involving other hazards.

This study is quantitative research that aims to examine the impact of disasters on fiscal balance at the provincial and district levels. We employed the fixed effects method and used the budgetary solvency ratio as the primary indicator at the district and provincial levels from 2010 to 2018 for Indonesia. We analyzed each budgetary solvency component, including own-source revenue, unexpected expenditure, capital expenditure, and consumption expenditure. Independent variables used to measure the effects of disasters include the number of death and missing people. Affected people variables include injured and displaced people. The number of damaged buildings includes houses, public buildings (for example, schools, places of worship, and health facilities), and private buildings (for example, factories and offices). We also used length of damaged roads and area of damaged forest to capture disaster severity. We used secondary data provided by related ministries/national entities for all variables. This research can serve as a basis for considering policy formulation for disaster mitigation and disaster financing.

Section 2 explains the concept of fiscal balance and how it is impacted by disasters. Section 3 explains our dataset and the econometric model. Section 4 presents our results, a discussion, and the limitations of this study.

\section{Economic and Fiscal Impacts of Disasters}

Botzen et al. (2019) classified the economic and fiscal impacts of disasters as either direct or indirect. The direct fiscal impacts usually arise on the side of expenditures. There are three types of post-disaster financing in
Indonesia: emergency response, rehabilitation, and reconstruction (Ministry of Finance 2018). Emergency response financing is used to find or rescue casualties, construct basic infrastructure for displaced people, and provide the necessary materials to meet people's basic needs. Rehabilitation financing is used to restore the social and economic conditions of the community. Reconstruction financing goes to repairing damaged public facilities. Local governments must prioritize the reconstruction of health facilities and educational facilities, as both fulfill basic community needs and significantly impact economic growth (Noy and Edmonds 2019).

The increased expenditure necessary in the aftermath of disasters impacts both local and central governments. Unterberger (2017) and Benali et al. (2019) found that disasters may increase the debt of local governments with limited fiscal capacity. In countries that embrace a decentralized system, this can be addressed through transfers from the central government. Deryugina (2017) and Miao et al. (2018) also found that disasters lead to significantly higher rates of transfers from central governments to regional governments.

Gross domestic product (GDP) is often used to quantify the indirect economic impact of disasters (Botzen et al. 2019). Based on previous studies, disasters can have varying effects-both positive and negative-on GDP (Chhibber and Laajaj 2008; Panwar and Sen 2019; Strulik and Trimborn 2019). If a disaster causes severe damage, GDP tends to decrease; however, if the damage from a disaster is minor, GDP tends to increase (Chhibber and Laajaj 2008). Strulik and Trimborn (2019) found that the effects of disasters on GDP depend on a community's welfare spending. If a disaster occurs in a country with high welfare spending, GDP may grow as a result of citizens' increasing consumption to replace assets that were destroyed.

Another economic indicator commonly used to assess the indirect impact of disasters is government revenue. Unsurprisingly, the effect of disasters on budget revenue is largely negative, as they result in welfare losses and fewer funds available to finance projects, repay debts, or create reserves in the short term (Unterberger 2017). In turn, revenues stemming from sales, property, income, and consumption taxes, and local levies decrease (Noy and Nualsri 2011; Miao et al. 2018).

The effect of disasters on government revenue can be examined in both the short and long terms. Using the vector auto-regressive panel method, Ouattara et al. (2018) found that tropical storms in the Caribbean resulted in decreased government revenues over the year in which the disaster occurred. A USD 1 increase in damage caused by disasters led to a reduction of USD 8 in government revenue. Using the same method, Benali et al. (2019) found 
that disasters involving flooding, earthquakes, and hurricanes significantly reduced government revenues in developing countries over a two-year period and in developed countries over a one-year period.

Several related studies have been conducted for different types of data and study locations. Lis and Nickel (2010) and Noy and Nualsri (2011) both conducted studies in developed and developing countries using aggregated data. Lis and Nickel (2010) used the debt-to-GDP ratio as their dependent variable while Noy and Nualsri (2011) used state revenue and spending policy as their dependent variables. Lee et al. (2018) looked at LDCs using aggregated data and found that disasters could increase government expenditure and reduce state revenue. Miao et al. (2018) and Deryugina (2017) both used disaggregated data to assess the impact of disasters on local government expenditure in the United States and found that disasters can increase the level of central government expenditure on transfers to regions.

Miao et al. (2018) analyzed the effects of disasters on the revenue and expenditure of state governments in the United States. They found that revenue from sales, property, and income taxes was not affected by disasters. This is related to government tax policy, such as the provision of income tax relief for disaster-affected people and reappraisal of property values following disaster, which could result in a lower tax base on property tax. In line with Noy and Nualsri's (2011) findings, this may happen because the central government in developed countries tends to lower tax rates and increase spending to restore fiscal balance and stabilize long-term tax revenues. In terms of expenditure, their study shows that disasters lead to increased local government spending to finance disaster-recovery programs but do not lead to increased capital expenditure.

Several disaster impact studies were also conducted in LDCs and small island developing states (SIDS). With the random effects method, Lee et al. (2018), who used aggregated data from $12 \mathrm{LDCs}$, found that disasters negatively and significantly affect economic growth, fiscal balance, and trade balance. Noy and Edmonds (2019) found a robust negative correlation between disasters and fiscal conditions in five SIDS. Disaster insurance schemes, such as the Pacific Catastrophe Risk Insurance, did not necessarily help.

Demographics play a key role in the impact of disasters on government revenue and expenditure. Skidmore and Toya (2013) used population density and fertility rates as control variables. Their study showed a strong positive correlation between population growth and government revenue. Fertility rates, however, were insignificant.

\section{Methodology}

In this section, we discussed the data and estimating model that were employed. We went through the various types of data and data sources in detail in the data section. Then, in the model estimation section, we described the dependent and independent variables as well as method and equations. We also presented an overview of using the selected data, as well as relevant literature that we employed to determine the model's specifications.

\subsection{Data}

We used data at the district and provincial levels from 2010 to 2018. The law that currently regulates local taxes and levies in Indonesia was enacted at the end of 2009. To limit bias caused by excessive variation, we did not use data from before 2010. We used unbalanced panel data, as regional expansion occurred during the period under review. We used two kinds of data: fiscal data and disaster data.

Fiscal data consist of local own-source revenue, capital expenditure, consumption expenditure, social assistance expenditure, and unexpected expenditure. All fiscal data were provided by the Directorate-General for Financial Balance at the Indonesian Ministry of Finance (MoF). In line with Ouattara et al. (2018), we converted all values into natural logged form. Local own-source revenue includes local taxes, levies, and other authorized sources such as profits from the selling of local assets, goods, and services; interest income from savings; currency exchange profits; and compensation. At the district and provincial government levels, different types of taxes are levied. Parking, hotel and restaurant, property, and other taxes are examples of local tax sources at the district level, while the motor vehicle, cigarette, and surface water taxes are local tax sources at the provincial level.

The primary dependent variable used to measure fiscal balance is the budgetary solvency ratio. The concept of fiscal balance in government is a condition under which government revenues can meet government expenditures (Chapman 2008). Fiscal balance is essential for local governments to maintain the level and quality of public services, maintain expenditures, and avoid widening the deficit during recessions (Honadle et al. 2004; Jimenez 2009). There are two classifications of fiscal balance at the local government level: standardized fiscal health and actual fiscal health (Honadle et al. 2004). Standardized fiscal balance denotes the government's ability to manage its revenues and expenditures without assistance from the central government; actual fiscal balance, in contrast, considers assistance from the central government. We used 
standardized fiscal balance to capture the capacity of each region to respond to disasters.

Budgetary solvency is the government's ability to generate revenue in order to meet its expenditure needs (Bisogno et al. 2019). Budgetary solvency comprises aspects of revenue capacity and expenditure pressure. The value is essential for examining the independence and sustainability of fiscal conditions at the level of local government. If budgetary solvency reaches one or greater, it indicates good fiscal capabilities, as it can finance its expenditures (Alam and Hoque 2019). Using Eq. 1, we calculated the budgetary solvency ratio by dividing local own-source revenue by disaster-related expenditures. Other fiscal factors that we used as dependent variables to explain the effect of disasters on budgetary solvency include local own-source revenue, capital expenditure, consumption expenditure, social assistance expenditure, and unexpected expenditure. management, such as forest produce fees and timber utilization permits. On the expenditure side, bias is closely related to the government authority in forest fire control. Based on Indonesian regulation, when the effects of a forest fire are limited to a single district, that district is responsible for managing the fire. However, if other districts are impacted, responsibility lies at the provincial level or even with the central government. As forest fires produce smog, which impacts the surrounding area, forest fire management is generally the responsibility of provincial governments. As a result, data on damaged forests are only appropriate at the provincial level.

The impact of disasters on fiscal balance is closely related to demographic and economic conditions. Therefore, we used population density (POPDEN) and gross regional domestic product per capita (GRDPCAP) as control variables, in line with Deryugina (2017) and Unterberger (2017). We used nominal GRDP, as the fiscal

Budgetary Solvency $_{i, t}=\left[\sum_{t=1}^{n} \frac{\text { LocalOwn }- \text { Source Revenue }_{i, t}}{\text { Capital Expenditure }_{i, t}+\text { Consumption Expenditure }_{i, t}+\text { Social Assistance Expenditure }_{i, t}+\text { Unexpected Expenditure }_{i, t}}\right]$

Data often used to detail the magnitude of disasters include the number of people killed, injured, and affected, and the economic damages (Shabnam 2014; Unterberger 2017; Miao et al. 2018; Tang et al. 2019). Due to the limited availability of data at the district level, we used the number of damaged buildings instead of the economic damages. The data on disaster severity were provided by the National Agency for Disaster Management (NADM). These data include the death toll and missing people; the number of people injured and displaced; the number of damaged houses; the number of damaged public buildings, including schools, health facilities, and places of worship; the number of damaged private buildings, including offices and factories; damaged roads (length); and the area of damaged forests. To normalize the severity data in line with Noy and Nualsri (2011), Wu et al. (2018), and Tang et al. (2019), it is divided by its total exposure or economic condition.

We only used damaged forest data at the provincial level, as the estimation at the district level contains a bias on the revenue and expenditure sides. On the revenue side, the area of damaged forests is biased at the district level because forest fires are closely associated with the forest area owned by the region. Districts with large forest areas tend to have higher local own-source revenue than those with small forest areas. Local own-source revenue is derived from taxes and levies related to forest data that we used contain elements of inflation. These data were published by the Indonesian Central Bureau of Statistics (CBS). The values of POPDEN and GRDPCAP variables were converted into natural logged form.

\subsection{Estimation Model}

We employed the fixed effects method to reduce the risk of omitted variable bias. This method was also used by Bergholt and Lujala (2012) to investigate the impact of disasters on economic growth as well as Leppänen et al. (2017) to investigate the impact of climate change on regional expenditure. We applied a robust estimation to solve the heteroscedasticity issue. This approach also helps to solve the problem of autocorrelation (Cermeño and Grier 2006).

The post-disaster financing process for rehabilitation and reconstruction should be viewed in the medium/long term. The reconstruction of buildings and the procurement of goods following a disaster constitute a time-consuming process. To accommodate the delay in post-disaster financing, we used an estimation model with one year and two year lags. To test the robustness, we also included a time fixed effect (in two additional models). The models used in this study are: 
Model 1, which uses Eq. 2, is a severity function in which each regressor interacts partially with dependent variables, in line with Tang et al. (2019).

$y_{i, t}^{l, m, k}=\alpha_{0}+\sum_{j=0}^{2} \beta_{j} D M_{k, i, t-j}+\sum_{g=1}^{2} \gamma_{g} X_{g, i, t}+\theta_{i}+\varepsilon_{i t}$

Model 2, which uses Eq. 3, is a severity function in which all regressors interact simultaneously with dependent variables, in line with Shabnam (2014) and Unterberger (2017)

$y_{i, t}^{l, m}=\alpha_{0}+\sum_{j=0}^{2} \sum_{k=1}^{7} \sigma_{j} D M_{k, i, t-j}+\sum_{g=1}^{2} \gamma_{g} X_{g, i, t}+\theta_{i}+\varepsilon_{i t}$

where:

- $y_{i, t}$ is the dependent variable in region $i$ and period $t$.

- $l=1,2,3,4,5,6 ; l$ is an independent variable consisting of (1) budgetary solvency, (2) local own-source revenue, (3) social assistance expenditure, (4) unexpected expenditure, (5) capital expenditure, and (6) consumption expenditure.

- $\quad m=1,2 ; m$ is the level of government where $1=$ district level, 2 = provincial level.

- $\alpha_{0}$ is the usual constant term.

- $j=$ time-year lag

- $D M$ is a variable that indicates the damage or severity of disasters.

- $k=1,2,3,4,5,6 ; k$ is a variable that indicates the type of damage consisting of (1) fatalities, (2) affected people, (3) damaged houses, (4) damaged public buildings, (5) damaged private buildings, (6) damaged roads, and (7) damaged forests. All data were normalized. Fatalities, affected people, and damaged houses were divided by total population; damaged public buildings and damaged private buildings were divided by GRDP; damaged roads were divided by population density; damaged forests were divided by total area.

- $X_{g}$ is a control variable, where $g=1$ for population density (POPDEN), $g=2$ for GRDP per capita (GRDPCAP).

- $\theta_{i}$ is a region fixed effect.

$-\varepsilon_{i t}$ is an error term.

\section{Results and Discussion}

We divided this section into three parts: descriptive statistics, estimation results using the regression model, and limitation of this study. We used descriptive statistics to examine the data in general, focusing on the classification of each indicator used, such as fiscal indicators and disaster severity indicators. We showed our main results in the section estimation results. This study still needs to be developed. Thus, in the final part of this section, we presented our potential development of this study.

\subsection{Statistics of Fiscal and Disaster Severity Indicators}

Disaster impacts from 2010-2018 are shown in Figs. 1 and 2. The two figures show that there is no significant difference in the pattern of the distribution of the casualties (fatalities and affected people) parameter and the building damage parameter from the disaster, except in the central Kalimantan area, where the casualties parameter is low but the building damage parameter is high. There is a similar pattern between casualties and building damage in other areas. These two parameters are evenly distributed throughout Java and Sulawesi. They are equally distributed in the southwest of Sumatra. On Papua, they are higher in the north than in the south.

Multiple previous studies have proven that geographical conditions influence the impact of disasters on the economy (Lis and Nickel 2010; Skidmore and Toya 2013; Deryugina 2017). Regional elevation may be used as one of the geographical indicators to assess the impact of disasters. Escaleras and Register (2012) and Skidmore and Toya (2013) employed regional average elevation as the independent variable in their models. We did not include elevation as an independent variable in our model since the topographic feature in Indonesia varies even within the same district. But we classified each district into lowland and highland categories to determine whether there is a statistical relationship between elevation and disaster severity. Based on the criteria used by the Indonesia Geospatial Information Agency, regional elevation could be categorized into lowland districts with elevations of less than $500 \mathrm{~m}$ above sea level and highland districts with elevations of more than $500 \mathrm{~m}$ above sea level, therefore we adopted this classification in using the data provided by the CBS (Table 1).

The averages for fatalities, buildings damaged, and roads damaged in lowland districts are higher than those in highland districts (see Table 1). This finding contrasts with that of Skidmore and Toya (2013), who found that the death toll in highland countries is higher than that in lowland countries. Their study looked at various types of hazards in both types of countries. Common hazards in lowland countries include floods and landslides, while hazards and disasters in highland countries include volcanic eruptions and earthquakes. In the context of Indonesia, the frequency of disasters is higher in the lowland regions than in the highland regions. The types of 


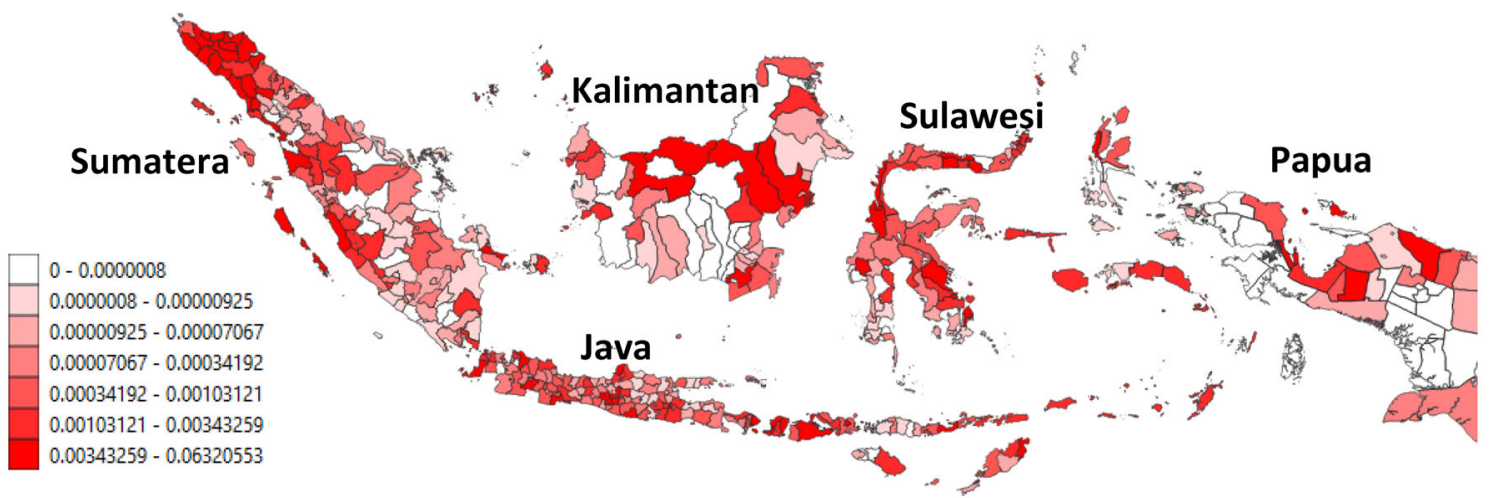

Fig. 1 Total ratio of casualties (fatalities and affected people) to population in Indonesia in 2010-2018. Source National Agency for Disaster Management (NADM) and Indonesian Central Bureau of Statistics (CBS); authors' calculations

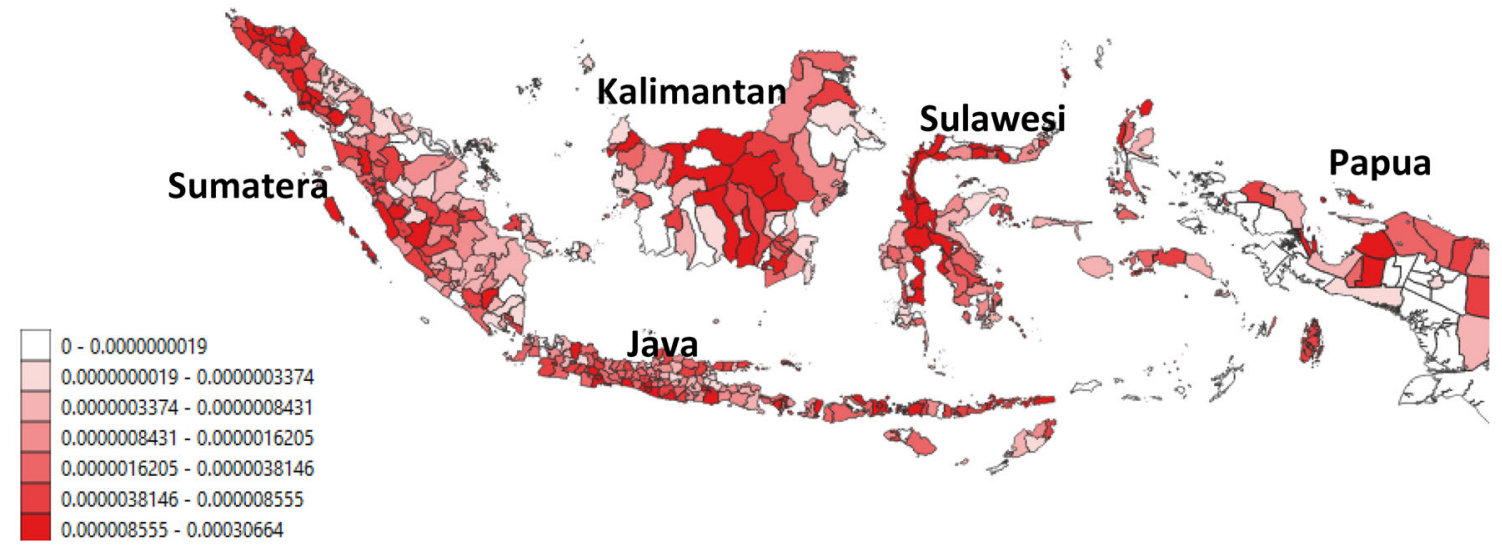

Fig. 2 Total ratio of building damage (public and private) to gross regional domestic product (GRDP) in Indonesia in 2010-2018. Source National Agency for Disaster Management (NADM) and Indonesian Central Bureau of Statistics (CBS); authors' calculations

disasters that generate significant numbers of casualties and damaged buildings, such as those that involve the hazards of earthquakes and tsunamis, are more common in lowland regions.

The impact of disasters on fiscal balance depends on population density (Ibarraran et al. 2009; Deryugina 2017;
Bisogno et al. 2019). Based on these facts-Java is Indonesia's most populous island, with a population density eight times that of the national average; the area of this island is just $6.75 \%$ of the overall area of Indonesia, yet according to the 2020 population census conducted by CBS, the population of Java is 270.2 million people or

Table 1 Disaster impact at the district level by elevation category in Indonesia in 2010-2018

\begin{tabular}{|c|c|c|c|c|c|c|}
\hline \multirow[t]{2}{*}{ Variable } & \multicolumn{3}{|c|}{ Lowland } & \multicolumn{3}{|c|}{ Highland } \\
\hline & Min & Max & Average & Min & Max & Average \\
\hline Fatalities & 0 & 0.01 & 0.0000118 & 0 & 0.0004 & $4.5 \times 10^{-6}$ \\
\hline Affected people & 0 & 0.57 & 0.0025163 & 0 & 0.29 & 0.0026 \\
\hline Houses_Damaged & 0 & 0.23 & 0.0005469 & 0 & 0.07 & 0.000347 \\
\hline Public_Buildings_Damaged & 0 & 0.00025 & $4.72 \times 10^{-7}$ & 0 & 0.0002 & $1.02 \times 10^{-6}$ \\
\hline Private_Buildings_Damaged & 0 & 0.00016 & $1.63 \times 10^{-7}$ & 0 & 0.00002 & $1.07 \times 10^{-7}$ \\
\hline Roads_Damaged & 0 & 18.36 & 0.015422 & 0 & 2.75 & 0.0056 \\
\hline Number of Observations & 3,613 & & & 841 & & \\
\hline
\end{tabular}

Source National Agency for Disaster Management (NADM); authors' calculations 
$56.1 \%$ of the total population of Indonesia - we divided our data into two segments: on Java and outside Java (Table 2). The averages for disaster frequency, casualties, and buildings damaged are higher on Java than outside Java. This finding is in line with Ibarraran et al. (2009), who found that higher population density leads to higher death tolls. However, the ratio of casualties to population (total of fatalities and affected people variable) and the ratio of buildings damaged (total of houses damaged, private buildings damaged, and public buildings damaged variable) to GRDP is higher outside Java than on Java. Importantly, disasters with a high degree of severity are more common outside Java than on Java.

Additionally, fatalities may be influenced by the level of trade openness, education, and inequality (Ibarraran et al. 2009; Skidmore and Toya 2013). People with low incomes and education levels, in general, have lack ability to adapt and dealing with disasters. Also, poor people who live in disaster-prone areas will be unable to migrate due to financial constraints. Then, because trade openness is linked to technological transfer, it can have an impact on the number of disaster victims (Skidmore and Toya 2013; Panwar and Sen 2019). Countries with a high level of trade openness will find it easier to transfer technology from countries with better technology. Countries could use technology to practice and improve disaster-related safety tools and infrastructures. By doing so, the country can reduce disaster-related fatalities.

The average budgetary solvency ratio is higher on Java than outside Java, as Java's large population produces higher local own-source revenue than districts outside Java.
Budgetary solvency outside Java has a very wide range of values between the minimum of 0.003 and the maximum of 3.345. This suggests disparities in fiscal capacity between districts outside Java.

The number of casualties, and buildings damaged by disasters in Indonesia have fluctuated, but show a rising trend over the last four years (Fig. 3). There is an increasing trend in the proportion of the number of casualties among the population between 2015 and 2018. The ratio of total buildings damaged to total disasters shows a similar trend.

Disasters in Indonesia most commonly involve flooding; the most impactful disasters, however, involve a combination of earthquake and tsunami (Table 3). Flooding resulted in the highest number of affected people-but combined earthquakes and tsunamis resulted in the highest death toll. While this combination occurred just five times between 2010 and 2018, it resulted in enormous numbers of deaths, affected people, and damaged buildings.

\subsection{Estimation Results}

This research used the fixed effects method. The results of the estimation model examining the effect of disasters on fiscal balance at the district level are shown in Table 4 while the effect at the provincial level is shown in Table 5. Almost all disaster severity variables show significant negative values for the fiscal balance at both the district and provincial levels. Several variables, including fatalities, affected people, damaged houses, damaged private buildings, and damaged roads negatively affect fiscal

Table 2 Statistics of all variables at the district level on Java and outside Java in 2010-2018

\begin{tabular}{|c|c|c|c|c|c|c|}
\hline \multirow[t]{2}{*}{ Variable } & \multicolumn{3}{|c|}{ Java Island } & \multicolumn{3}{|c|}{ Outside Java Island } \\
\hline & Min & Max & Average & Min & Max & Average \\
\hline Budgetary solvency & 0.093 & 1.623 & 0.416 & 0.003 & 3.345 & 0.165 \\
\hline Frequency of disasters & 0 & 111 & 10.95 & 0 & 43 & 2.42 \\
\hline Number of casualties & 0 & 182,912 & $1,991.002$ & 0 & 126,281 & 710.43 \\
\hline Fatalities & 0 & 0.0002 & $2.25 \times 10^{-6}$ & - & 0.011 & 0.0000128 \\
\hline Affected people & 0 & 0.149 & 0.002 & 0 & 0.567 & 0.003 \\
\hline Houses_damaged & 0 & 0.0204 & 0.0002 & 0 & 0.234 & 0.0006 \\
\hline Public_buildings_damaged & 0 & 0.437 & $1.45 \mathrm{e}^{-07}$ & 0 & 0.0002485 & $7.02 \times 10^{-7}$ \\
\hline Private_buildings_damaged & 0 & 0.000011 & $5.66 \times 10^{-8}$ & 0 & 0.00016 & $1.80 \times 10^{-7}$ \\
\hline Roads damaged & 0 & 3.213 & 0.0045 & 0 & 18.356 & 0.0162 \\
\hline Population density (ln) & 5.6 & 9.67 & 7.31 & -0.46 & 9.19 & 4.49 \\
\hline GRDP per capita (ln) & 15.99 & 19.92 & 17.12 & 15.03 & 19.94 & 17.20 \\
\hline Number of observations & 1,012 & & & 3,442 & & \\
\hline
\end{tabular}

Source National Agency for Disaster Management (NADM) and Ministry of Finance; authors' calculations. GRDP = Gross Regional Domestic Product. $\ln =$ Natural logged form 
Fig. 3 Trend of the number of casualties (fatalities and affected people) and buildings damaged by disasters in Indonesia in 2010-2018. Source National Agency for Disaster Management (NADM); authors' calculations

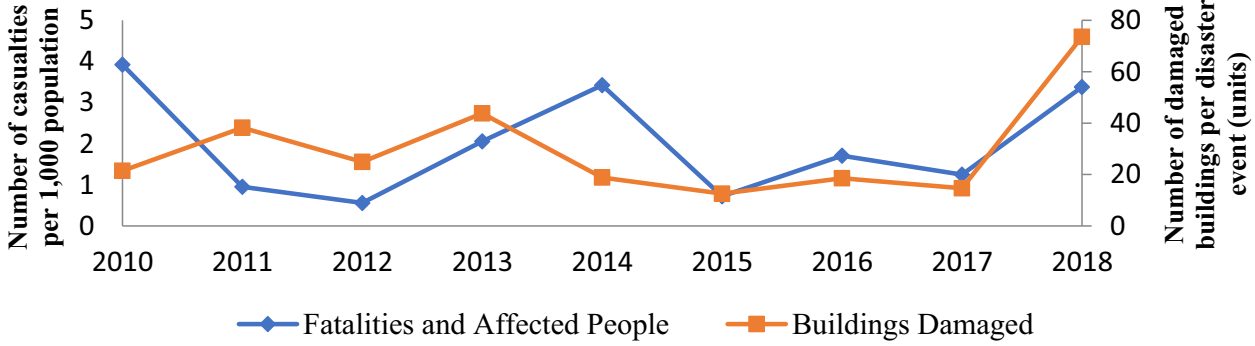

Table 3 Number of casualties and building damage stemming from each type of disaster in Indonesia in 2010-2018

\begin{tabular}{|c|c|c|c|c|c|c|c|}
\hline \multirow[t]{2}{*}{ Hazards } & \multirow{2}{*}{$\begin{array}{l}\text { Number of } \\
\text { Events }\end{array}$} & \multicolumn{2}{|l|}{ Fatalities } & \multicolumn{2}{|c|}{ Affected people } & \multicolumn{2}{|c|}{ Buildings damaged } \\
\hline & & $\begin{array}{l}\text { Total } \\
\text { (persons) }\end{array}$ & $\begin{array}{l}\text { Average (persons/ } \\
\text { event) }\end{array}$ & $\begin{array}{l}\text { Total } \\
\text { (persons) }\end{array}$ & $\begin{array}{l}\text { Average (persons/ } \\
\text { event) }\end{array}$ & $\begin{array}{l}\text { Total } \\
\text { (units) }\end{array}$ & $\begin{array}{l}\text { Average (units/ } \\
\text { event) }\end{array}$ \\
\hline Floods & 6863 & 2006 & 0.29 & $2,630,494$ & 383 & 181,475 & 26.44 \\
\hline Storms & 5775 & 322 & 0.06 & 19,195 & 3 & 187,869 & 32.53 \\
\hline Landslides & 4504 & 1801 & 0.4 & 90,936 & 20 & 34,897 & 7.75 \\
\hline Forest Fires & 1076 & 36 & 0.03 & 852 & 1 & 132 & 0.12 \\
\hline Droughts & 754 & 2 & 0 & 0 & 0 & 1 & 0 \\
\hline Earthquakes & 246 & 763 & 3.10 & 636,688 & 2588 & 300,866 & $1,223.03$ \\
\hline Coastal Erosion & 207 & 67 & 0.32 & 8860 & 43 & 4411 & 21.31 \\
\hline Volcanic Eruptions & 135 & 432 & 3.2 & 848,034 & 6282 & 21,163 & 156.76 \\
\hline Tsunamis & 20 & 968 & 48.4 & 72,311 & 3616 & 363 & 181.5 \\
\hline $\begin{array}{l}\text { Earthquake and } \\
\text { Tsunami }\end{array}$ & 5 & 4846 & 969.2 & 225,888 & 45,178 & 112,472 & $22,494.4$ \\
\hline
\end{tabular}

Source National Agency for Disaster Management (NADM); authors' calculations.

balance at the district level. At the provincial level, damaged roads and damaged forests both show a significant negative value for budgetary solvency. Only the affected people variable indicates a significantly positive effect on budgetary solvency. To examine the cause of this difference, we estimated each fiscal component (see Table 4).

We regressed all independent variables simultaneously (Model 2) to test robustness; this is shown in Table 4 (column 7) for data at the district level and Table 5 (column 8) for data at the provincial level. Our estimated results suggest that the direction in the simultaneous model is consistent with the direction in the partial model. The damaged roads variable consistently has a significant negative impact on budgetary solvency at the district level. The damaged roads and damaged forests variables consistently have a significant negative impact on budgetary solvency at the provincial level.

Population density and GRDP per capita are used as control variables at all government levels. Both districts and provinces show significant value despite the different directions. For data at the district level, population density and GRDP per capita show a positive direction toward budgetary solvency. For data at the provincial level, population density shows a positive direction toward budgetary solvency but GRDP per capita shows a negative direction. This directional difference likely stems from the differences in tax types between the two government levels. Provincial government taxes are mostly derived from taxes related to motor vehicles; the increase in GRDP per capita is not always accompanied by an increase in the number of vehicles or the use of fuel.

Fatalities significantly affect fiscal balance at the district level in the year in which disasters occur (see Table 4, column 1); however, this significant relationship does not exist at the provincial level. The risk of fiscal balance at the district level occurs due to the decrease in local own-source revenue and the increase in spending on goods and services. Although the fiscal balance at the provincial level does not show a significant value (see Table 5, column 1), fatalities significantly lower local own-source revenue and increase unexpected spending. This decline in own-source revenue is in line with Miao et al. (2018), who found that disasters significantly reduce government revenues from property and sales taxes due to a decrease in income and consumption. Miao et al. (2018) argued that disasters can also lead to the migration of people from disaster-prone 
Table 4 Estimated effects of disaster severity on budgetary solvency variables at the district level in Indonesia in 2010-2018

\begin{tabular}{|c|c|c|c|c|c|c|c|}
\hline & $\begin{array}{l}\text { (1) } \\
\text { BS }\end{array}$ & $\begin{array}{l}\text { (2) } \\
\text { BS }\end{array}$ & $\begin{array}{l}\text { (3) } \\
\text { BS }\end{array}$ & $\begin{array}{l}\text { (4) } \\
\text { BS }\end{array}$ & $\begin{array}{l}\text { (5) } \\
\text { BS }\end{array}$ & $\begin{array}{l}\text { (6) } \\
\text { BS }\end{array}$ & $\begin{array}{l}\text { (7) } \\
\text { BS }\end{array}$ \\
\hline Fatalities & $-2.884 * * *$ & & & & & & 0.534 \\
\hline L1.Fatalities & -18.73 & & & & & & -10.49 \\
\hline L2.Fatalities & $3.552 * *$ & & & & & & \\
\hline Affected People & & $-0.118^{*}$ & & & & & -0.108 \\
\hline L1.Affected People & & -0.035 & & & & & 0.010 \\
\hline L2.Affected People & & -0.088 & & & & & \\
\hline Houses_Damaged & & & $-0.214 * *$ & & & & 0.004 \\
\hline L1.Houses_Damaged & & & -0.353 & & & & 0.0270 \\
\hline L2.Houses_Damaged & & & -0.312 & & & & -0.079 \\
\hline Public_Buildings_Damaged & & & & -114.0 & & & 57.92 \\
\hline L1.Public_Buildings_Damaged & & & & -171.9 & & & -132.5 \\
\hline L2.Public_Buildings_Damaged & & & & -158.5 & & & -115.8 \\
\hline Private_Buildings_Damaged & & & & & $-1773.7 * *$ & & -1409.5 \\
\hline L1.Private_Buildings_Damaged & & & & & $-561.1 * *$ & & -428.1 \\
\hline L2.Private_Buildings_Damaged & & & & & -225.0 & & -207.0 \\
\hline Roads_Damaged & & & & & & $-0.003 * * *$ & $-0.003 * * *$ \\
\hline L1.Roads_Damaged & & & & & & -0.000008 & 0.0002 \\
\hline L2.Roads_Damaged & & & & & & -0.0004 & 0.0005 \\
\hline POPDEN & $0.074 * * *$ & $0.074 * * *$ & $0.074 * * *$ & $0.074 * * *$ & $0.073 * * *$ & $0.073 * * *$ & $0.073 * * *$ \\
\hline GRDPCAP & $0.081 * * *$ & $0.081 * * *$ & $0.080 * * *$ & $0.080 * * *$ & $0.080 * * *$ & $0.0802 * * *$ & $0.080 * * *$ \\
\hline _cons & $-1.537 * * *$ & $-1.537 * * *$ & $-1.530 * * *$ & $-1.532 * * *$ & $-1.520 * * *$ & $-1.529 * * *$ & $-1.523 * * *$ \\
\hline$N$ & 3433 & 3433 & 3433 & 3433 & 3433 & 3433 & 3433 \\
\hline$R^{2}$ & 0.048 & 0.049 & 0.049 & 0.048 & 0.049 & 0.048 & 0.050 \\
\hline adj. $R^{2}$ & 0.047 & 0.048 & 0.047 & 0.047 & 0.047 & 0.047 & 0.045 \\
\hline F - stat & 27.48 & 27.48 & 26.93 & 24.33 & 28.52 & 32.58 & 11.44 \\
\hline Prob $>F$ & 0.000 & 0.000 & 0.000 & 0.000 & 0.000 & 0.000 & 0.000 \\
\hline
\end{tabular}

***Significant at the level of $1 \%$;* Significant at the level of $5 \%$; Significant at the level of $10 \%$.

BS = Budgetary Solvency; POPDEN = Population Density (in natural logged form); GRDPCAP = Gross Regional Domestic Product per Capita (in natural logged form); L1 = One year lag; L2 = Two year lag.

areas to other regions. This finding is consistent with Benali et al. (2019), who found that economic contraction stemming from disasters may decrease the government's capacity to earn revenue from standard tax collection. The increase in local own-source revenue in the year following a disaster is in line with Benson and Clay's (2004) assessment that disasters cause those who are affected to postpone their tax payments.

The affected people variable negatively and significantly affects fiscal balance at the district level in the year in which disasters occur (see Table 4, column 2); it positively and significantly affects fiscal balance at the provincial level one year after the disaster occurred. Increased consumption expenditure harms fiscal balance, resulting in the negative effect at the district level. The positive effect of disasters on fiscal balance at the provincial level stems from an increase in local own-source revenue and a decrease in consumption expenditure at one year lag (see
Table 5, column 2). Declining consumption expenditure is thought to be due to the reallocation of funds to other expenditures, such as social assistance and capital (although neither of these generates significant value).

Houses damaged by disasters significantly negatively affect the fiscal balance at the district level in the year in which disasters occur (see Table 4, column 3); however, they do not significantly affect the fiscal balance at the provincial level (see Table 5, column 3). The decrease at the district level is due to increased consumption expenditure. While the effect on the fiscal balance at the provincial level is insignificant, our model shows that disasters increase unexpected expenditure at the provincial level.

The damaged public buildings variable has no significant effect on the fiscal balance at the district level or the provincial level (see Table 4, column 4; Table 5, column 4). Capital expenditure is closely related to financing for 
Table 5 Estimated effects of disaster severity on budgetary solvency variables at the provincial level in Indonesia in 2010-2018

\begin{tabular}{|c|c|c|c|c|c|c|c|c|}
\hline & $\begin{array}{l}\text { (1) } \\
\text { BS }\end{array}$ & $\begin{array}{l}\text { (2) } \\
\text { BS }\end{array}$ & $\begin{array}{l}\text { (3) } \\
\text { BS }\end{array}$ & $\begin{array}{l}\text { (4) } \\
\text { BS }\end{array}$ & $\begin{array}{l}\text { (5) } \\
\text { BS }\end{array}$ & $\begin{array}{l}\text { (6) } \\
\text { BS }\end{array}$ & $\begin{array}{l}\text { (7) } \\
\text { BS }\end{array}$ & $\begin{array}{l}\text { (8) } \\
\text { BS }\end{array}$ \\
\hline Fatalities & 23.99 & & & & & & & 40.69 \\
\hline L1.Fatalities & 3532.3 & & & & & & & 2007.7 \\
\hline L2.Fatalities & -108.9 & & & & & & & \\
\hline Affected People & & 0.753 & & & & & & 3.074 \\
\hline L1.Affected People & & $4.790 *$ & & & & & & 5.722 \\
\hline L2.Affected People & & 2.586 & & & & & & \\
\hline Houses_Damaged & & & -0.844 & & & & & -6.324 \\
\hline L1.Houses_Damaged & & & 1.814 & & & & & -3.175 \\
\hline L2.Houses_Damaged & & & -3.216 & & & & & -0.616 \\
\hline Public_Buildings_Damaged & & & & -0.560 & & & & -2.668 \\
\hline L1.Public_Buildings_Damaged & & & & -4.363 & & & & -4.413 \\
\hline L2.Public_Buildings_Damaged & & & & -2.965 & & & & -1.993 \\
\hline Private_Buildings_Damaged & & & & & 46.56 & & & 49.38 \\
\hline L1.Private_Buildings_Damaged & & & & & -5.207 & & & $-6.329 *$ \\
\hline L2.Private_Buildings_Damaged & & & & & 0.862 & & & -0.211 \\
\hline Roads_Damaged & & & & & & $-0.019 * * *$ & & $-0.0202 * * *$ \\
\hline L1.Roads_Damaged & & & & & & 0.003 & & 0.002 \\
\hline L2.Roads_Damaged & & & & & & 0.005 & & 0.006 \\
\hline Forests_Damaged & & & & & & & $-0.0003 * * *$ & $-0.0003 * * *$ \\
\hline L1.Forests_Damaged & & & & & & & $-0.0005^{* * *}$ & $-0.0006 * * *$ \\
\hline L2.Forests_Damaged & & & & & & & $0.001 * * *$ & $0.001 * * *$ \\
\hline POPDEN & $0.667 * * *$ & $0.597 * * *$ & $0.678 * * *$ & $0.686^{* * * *}$ & $0.679 * * *$ & $0.683 * * *$ & $0.684 * * *$ & $0.571 * * *$ \\
\hline GRDPCAP & $-0.249 *$ & $-0.237 *$ & $-0.254 *$ & $-0.269 * *$ & $-0.254^{*}$ & $-0.263 * *$ & $-0.266^{* *}$ & $-0.256^{*}$ \\
\hline _cons & 0.465 & 0.666 & 0.461 & 0.589 & 0.454 & 0.536 & 0.561 & 0.994 \\
\hline$N$ & 229 & 229 & 229 & 229 & 229 & 229 & 229 & 229 \\
\hline$R^{2}$ & 0.056 & 0.059 & 0.052 & 0.055 & 0.102 & 0.068 & 0.109 & 0.197 \\
\hline adj. $R^{2}$ & 0.034 & 0.037 & 0.031 & 0.033 & 0.082 & 0.047 & 0.089 & 0.116 \\
\hline F - stat & 17.64 & 19.36 & 16.07 & 15.34 & 15.92 & 160.37 & $1.20 \times 10^{7}$ & $2.46 \times 10^{6}$ \\
\hline Prob $>F$ & 0.000 & 0.000 & 0.000 & 0.00 & 0.000 & 0.000 & 0.000 & 0.000 \\
\hline
\end{tabular}

*** Significant at the level of $1 \%$; * Significant at the level of $5 \%$; Significant at the level of $10 \%$

BS = Budgetary Solvency; POPDEN = Population Density (in natural logged form); GRDPCAP = Gross Regional Domestic Product per Capita (in natural logged form); L1 = One year lag; L2 = Two year lag

the reconstruction process. Based on the estimated results, the number of damaged public buildings significantly lowers capital expenditure at the district level. This suggests that the fiscal burden for reconstruction is borne by the provincial level—or even the central level—rather than the district level. Capital expenditure at the provincial level shows a positive direction at one year lag, though the value is insignificant. This may indicate two things: first, the reconstruction cost is not very high relative to the total cost of development at the provincial level; second, the reconstruction process takes a long time, as it consists of both planning and implementation (Benson and Clay 2004; Mochizuki et al. 2015). As a result, funding for reconstruction cannot be captured in our model, which uses a two year lag. If the lag was greater than two years, it would 
reduce the number of observations, and further research that uses a longer observation period would be needed.

The damaged private buildings variable reduces the fiscal balance at the district level in the same year and in the two years that follow (see Table 4, column 5); however, it does not significantly affect the fiscal balance at the provincial level (see Table 5, column 5). The decrease in fiscal balance at the district level stems from a decrease in local own-source revenue and an increase in consumption expenditure. Provincial governments also experience a decline in local own-source revenue due to the decrease in output borne by the private sector. These results are consistent with Narayan (2003), who found that 2003 Cyclone Ami in Fiji prompted a decrease in private-sector economic activity, which was reflected in the decline in investment and exports.

The damaged roads variable significantly negatively affects fiscal balance at the district and provincial levels (see Table 4, column 6; Table 5, column 6) through an increase in all types of expenditure, including social assistance expenditure, unexpected expenditure, capital expenditure, and consumption expenditure. Capital expenditure on road reconstruction increases significantly during the year in which a disaster occurs. This finding suggests that local governments at both the district and provincial levels are quite responsive in terms of road restoration.

The damaged forests variable significantly negatively affects fiscal balance at the provincial level (see Table 5, column 7). This negative impact stems from a decrease in local own-source revenue and increases in both social expenditure and capital expenditure. This is in line with Calkin et al. (2005), who found that spending by the central government in the United States between 1970 and 2002 was proportional to the increase in forest area burned. To prevent the adverse effects of forest fires on the fiscal balance, local governments require fire-prevention efforts conducted collectively with landowners and local communities.

Disasters may increase the burden of capital expenditure for two reasons. First, disasters can delay development projects, potentially burdening the fiscal balance in the year following a disaster. Our estimation in Table 6, panel 1 (fatalities) shows that disasters significantly lower capital expenditure during the year in which a disaster occurs but increase capital expenditure the following year. This suggests that disasters commonly delay preplanned development projects (Benson and Clay 2004). Second, disasters may increase capital expenditure due to the need for reconstruction and repair. The road reconstruction process can be completed quickly by district and provincial governments. This result is illustrated in Table 6, panel 6; the damaged roads variable positively and significantly affects capital expenditure during the year in which a disaster occurs. However, the reconstruction processes for other forms of public infrastructure may take far longer (Benson and Clay 2004). This result can be seen in Table 6, panel 2 (affected people variable), which shows that disasters significantly increase capital expenditure at the district level in the year following a disaster. These results stray from those of Ouattara et al. (2018), who found that disasters do not significantly affect capital expenditure in the Caribbean. Other resources, such as international aid, are likely a reason for the differences between our study and their study.

In addition to the partial model, we also ran a simultaneous model using Eq. 3. The results of this model can be seen in Table 4, column 7 for the district level and Table 5, column 8 for the provincial level. Our findings suggest that disasters have a strong negative impact on fiscal balance at both the district and provincial levels. These effects can be seen in the damaged roads variable. Based on these findings, local governments should adjust their fiscal policies in order to minimize higher disaster-related expenditures. One policy option is to provide disaster insurance. Another policy option is for local governments to issue a municipal bond. Disaster bonds may also be issued by central governments to finance post-disaster reconstruction.

We also estimated the fixed effect model by including the time fixed effect to check the robustness for data at the district level and the results were presented in Table 7. Our estimated model showed that the results in the model without the time fixed effect are consistent with the results in the model that includes the time fixed effect, even though there is a decrease in the number of significant variables in the model that includes the time fixed effect. Fatalities, private buildings damaged, and roads damaged showed the same direction in the estimation model with or without time fixed effect.

\subsection{Limitations of this Study}

This study has some limitations. First, we used data on the number of buildings damaged without calculating their economic value. Similar research has used the economic value of physical damage, which might more accurately reflect the magnitude of the disaster. Nevertheless, without detailed information, it is difficult to quantify the economic value of building damage. 
Table 6 Estimated result of disaster severity indicators on all fiscal variables (partial model) in Indonesia in 2010-2018

\begin{tabular}{|c|c|c|c|c|c|c|}
\hline \multirow[t]{2}{*}{ Government Level } & \multicolumn{3}{|l|}{ District Level } & \multicolumn{3}{|c|}{ Provincial Level } \\
\hline & $\mathrm{t}$ & $\mathrm{t}+1$ & $\mathrm{t}+2$ & $\mathrm{t}$ & $\mathrm{t}+1$ & $\mathrm{t}+2$ \\
\hline \multicolumn{7}{|l|}{ Panel 1: Fatalities } \\
\hline Budgetary Solvency & $-2.884 * * *$ & -18.73 & $3.552 * *$ & 23.99 & 3532.3 & -108.9 \\
\hline $\begin{array}{l}\text { Local Own-Source } \\
\text { Revenue }\end{array}$ & $-17.19 *$ & $466.7 *$ & $27.72 * * *$ & $-130.9 * * *$ & 1031.9 & $-1067.8 * * *$ \\
\hline $\begin{array}{l}\text { Social Assistance } \\
\text { Expenditure }\end{array}$ & $-324.6 * * *$ & -1950.9 & $-112.0^{*}$ & 665.2 & 78065.4 & 18831.1 \\
\hline Unexpected Expenditure & 113.0 & $7759.6^{*}$ & 792.0 & $1836.3 * *$ & -89015.1 & $-12507.4 * * *$ \\
\hline Capital Expenditure & $-46.75 * * *$ & $654.1 * * *$ & 11.16 & $-206.2 * * *$ & -7641.8 & -323.9 \\
\hline Consumption Expenditure & $24.51 *$ & $746.2 * * *$ & -4.112 & $-66.30 * *$ & $-7205.6 * *$ & $-534.5 * * *$ \\
\hline \multicolumn{7}{|l|}{ Panel 2: Affected People } \\
\hline Budgetary Solvency & $-0.118 *$ & -0.0346 & -0.0883 & 0.753 & $4.790^{*}$ & 2.586 \\
\hline $\begin{array}{l}\text { Local Own-Source } \\
\text { Revenue }\end{array}$ & 0.151 & $0.625 * * *$ & $0.514 * *$ & -0.821 & $4.938 * * *$ & 2.065 \\
\hline $\begin{array}{l}\text { Social Assistance } \\
\text { Expenditure }\end{array}$ & -1.022 & 3.131 & 1.032 & -10.61 & 189.5 & 134.7 \\
\hline Unexpected Expenditure & 7.502 & 10.41 & -3.008 & $77.92 *$ & -95.69 & 27.70 \\
\hline Capital Expenditure & 0.151 & $0.997 * *$ & 0.519 & -2.696 & 3.112 & 0.221 \\
\hline Consumption Expenditure & $0.596 * * *$ & -1.901 & $0.901 * *$ & 0.103 & $-9.758 * * *$ & $-7.142 * * *$ \\
\hline \multicolumn{7}{|l|}{ Panel 3: Houses_Damaged } \\
\hline Budgetary Solvency & $-0.214 * *$ & -0.353 & -0.312 & -0.844 & 1.814 & -3.216 \\
\hline $\begin{array}{l}\text { Local Own-Source } \\
\text { Revenue }\end{array}$ & -0.624 & -1.772 & 2.291 & -2.101 & -1.544 & 5.045 \\
\hline $\begin{array}{l}\text { Social Assistance } \\
\text { Expenditure }\end{array}$ & 2.982 & 8.031 & -15.30 & 37.77 & 634.7 & -99.29 \\
\hline Unexpected Expenditure & -8.189 & $-52.91^{*}$ & -47.00 & $84.28 * *$ & $-1691.5 * * *$ & $-1234.0^{*}$ \\
\hline Capital Expenditure & -1.114 & -2.633 & 1.609 & -3.949 & -12.97 & -19.53 \\
\hline Consumption Expenditure & $2.312 * * *$ & 2.232 & 1.930 & 3.969 & -5.140 & 5.916 \\
\hline \multicolumn{7}{|c|}{ Panel 4: Public_Buildings_Damaged } \\
\hline Budgetary Solvency & -114.0 & -171.9 & -158.5 & -0.560 & -4.363 & -2.965 \\
\hline $\begin{array}{l}\text { Local Own-Source } \\
\text { Revenue }\end{array}$ & -715.7 & -439.3 & -295.7 & $-4.048 *$ & $-2.139 *$ & 0.393 \\
\hline $\begin{array}{l}\text { Social Assistance } \\
\text { Expenditure }\end{array}$ & 206.2 & $4789.9 *$ & $8036.5^{*}$ & -27.14 & -77.23 & -114.7 \\
\hline Unexpected Expenditure & 3400.8 & 6982.0 & 519.0 & $125.4 * * *$ & 47.70 & 146.9 \\
\hline Capital Expenditure & $-892.2 * * *$ & -579.0 & -697.7 & $-5.261 * *$ & 0.852 & -0.615 \\
\hline Consumption Expenditure & 433.1 & 1118.2 & 278.1 & $7.016 * *$ & -1.056 & 1.871 \\
\hline \multicolumn{7}{|c|}{ Panel 5: Private_Buildings_Damaged } \\
\hline Budgetary Solvency & $-1773.7 * *$ & $-561.1 * * * *$ & -225.0 & 46.56 & -5.207 & 0.862 \\
\hline $\begin{array}{l}\text { Local Own-Source } \\
\text { Revenue }\end{array}$ & $-14259.5^{* * *}$ & $-6927.1 * *$ & $-3165.9^{* *}$ & -9.244 & $-6.212 * * *$ & $-3.611^{* * *}$ \\
\hline $\begin{array}{l}\text { Social Assistance } \\
\text { Expenditure }\end{array}$ & 29830.0 & 8322.5 & $32580.3^{* *}$ & -124.7 & -84.20 & -70.72 \\
\hline Unexpected Expenditure & -87516.0 & -44532.1 & -22275.0 & 64.33 & -71.21 & 189.4 \\
\hline Capital Expenditure & -9348.2 & $-7510.7 * * *$ & -2068.7 & -23.20 & -6.532 & -11.26 \\
\hline Consumption Expenditure & $74795.9^{*}$ & 19044.8 & 3721.8 & 2.132 & $-4.424 * *$ & $-4.700 * *$ \\
\hline \multicolumn{7}{|l|}{ Panel 6: Roads_Damaged } \\
\hline Budgetary Solvency & $-0.00306^{* * *}$ & -0.00000802 & -0.000406 & $-0.0188 * * *$ & 0.00335 & 0.00495 \\
\hline $\begin{array}{l}\text { Local Own-Source } \\
\text { Revenue }\end{array}$ & 0.00325 & $0.0110^{* * *}$ & -0.00719 & 0.000553 & $0.00569 * * *$ & -0.00213 \\
\hline
\end{tabular}


Table 6 continued

\begin{tabular}{|c|c|c|c|c|c|c|}
\hline \multirow[t]{2}{*}{ Government Level } & \multicolumn{3}{|c|}{ District Level } & \multicolumn{3}{|l|}{ Provincial Level } \\
\hline & $\mathrm{t}$ & $\mathrm{t}+1$ & $\mathrm{t}+2$ & $\mathrm{t}$ & $\mathrm{t}+1$ & $\mathrm{t}+2$ \\
\hline $\begin{array}{l}\text { Social Assistance } \\
\text { Expenditure }\end{array}$ & $0.586 * * *$ & $0.549 * * *$ & $0.568 * * *$ & $0.826 * * *$ & $0.716^{* * *}$ & $-0.401 * *$ \\
\hline Unexpected Expenditure & $0.707 * * *$ & $-0.330 * * *$ & 0.376 & $0.161 *$ & 0.0826 & 0.136 \\
\hline Capital Expenditure & $0.0235 * *$ & $0.0113 * * *$ & 0.000291 & $0.0215^{* * *}$ & 0.00191 & -0.0177 \\
\hline Consumption Expenditure & $0.0211 * * *$ & $0.0101 * *$ & $-0.00948^{*}$ & $0.00590 * * *$ & 0.000498 & 0.000281 \\
\hline \multicolumn{7}{|l|}{ Panel 7: Forests_Damaged } \\
\hline Budgetary Solvency & & & & $-0.000300 * * *$ & $-0.000533 * * *$ & $0.00132 * * *$ \\
\hline $\begin{array}{l}\text { Local Own-Source } \\
\text { Revenue }\end{array}$ & & & & $-0.000282 * * *$ & $-0.000316^{* * *}$ & $-0.000173 * * *$ \\
\hline $\begin{array}{l}\text { Social Assistance } \\
\text { Expenditure }\end{array}$ & & & & $0.00128^{*}$ & $0.00203 * * *$ & $0.00203 * * *$ \\
\hline Unexpected Expenditure & & & & $-0.0113 * * *$ & $-0.0109 * * *$ & $-0.0102 * * *$ \\
\hline Capital Expenditure & & & & $0.000452 * * *$ & $0.000579 * * *$ & $-0.00218 * * *$ \\
\hline Consumption Expenditure & & & & $-0.000339 * * *$ & $0.000150 * * *$ & $-0.000451 * * *$ \\
\hline
\end{tabular}

***Significant at the level of $1 \%$; * Significant at the level of $5 \%$; Significant at the level of $10 \%$; variable controls (population density and GRDP per capita) are considered throughout the entire model. $t=$ Year of observation. All fiscal variables (Local Own-Source Revenue, Social Assistance Expenditure, Unexpected Expenditure, Capital Expenditure, and Consumption Expenditure) are converted into natural logged form.

Second, we used annual data due to limited data availability. The results would have been more precise if we had used monthly data. Disasters that occur at the beginning of a year would have a larger impact on fiscal conditions in that year than those that occur at the end of a year, for which the impacts would be seen in the following fiscal year (Benali et al. 2019).

\section{Conclusion}

For Indonesia, disasters are shown to strain fiscal balance at both the district and provincial levels. At the district and provincial levels, the damaged roads variable demonstrated robust negative effects on fiscal balance. This decline in fiscal balance is largely due to a decrease in local ownsource revenue and increases in social assistance expenditure, unexpected expenditure, capital expenditure, and consumption expenditure. At the district level, the riskiest type of expenditure to be increased is consumption expenditure; at the provincial level, it is unexpected expenditure.

The findings of this study should encourage local governments to develop financing mechanisms to stabilize their fiscal operations amid disasters. Disaster-prevention planning through medium-term or long-term financing schemes is necessary to mitigate the adverse impacts of disasters on fiscal balance. Other financing instruments, such as disaster insurance or issuing bonds should be considered by all governments. While local governments have several options for post-disaster finance, the process of rehabilitation and reconstruction should not be delayed so that the accelerated output will be faster (Bevan and Cook 2015). 
Table 7 Estimated effects of disaster severity on budgetary solvency variables at the district level (includes time fixed effect)

\begin{tabular}{|c|c|c|c|c|c|c|c|}
\hline & $\begin{array}{l}\text { (1) } \\
\text { BS }\end{array}$ & $\begin{array}{l}\text { (2) } \\
\text { BS }\end{array}$ & $\begin{array}{l}\text { (3) } \\
\text { BS }\end{array}$ & $\begin{array}{l}\text { (4) } \\
\text { BS }\end{array}$ & $\begin{array}{l}\text { (5) } \\
\text { BS }\end{array}$ & $\begin{array}{l}\text { (6) } \\
\text { BS }\end{array}$ & $\begin{array}{l}\text { (7) } \\
\text { BS }\end{array}$ \\
\hline Fatalities & $-1.634 * *$ & & & & & & 0.626 \\
\hline L1.Fatalities & $-80.31 * *$ & & & & & & -53.83 \\
\hline L2.Fatalities & $4.890 * * *$ & & & & & & \\
\hline Affected people & & -0.101 & & & & & -0.110 \\
\hline L1.Affected people & & -0.0861 & & & & & -0.0202 \\
\hline L2.Affected people & & -0.0766 & & & & & \\
\hline Houses_Damaged & & & -0.142 & & & & 0.0505 \\
\hline L1.Houses_Damaged & & & -0.594 & & & & 0.0466 \\
\hline L2.Houses_Damaged & & & -0.188 & & & & -0.0583 \\
\hline Public_Buildings_Damaged & & & & -26.13 & & & 117.0 \\
\hline L1.Public_Buildings_Damaged & & & & -243.7 & & & -178.1 \\
\hline L2.Public_Buildings_Damaged & & & & -95.65 & & & -74.30 \\
\hline Private_Buildings_Damaged & & & & & -1232.1 & & -1130.2 \\
\hline L1.Private_Buildings_Damaged & & & & & $-349.2 *$ & & -43.34 \\
\hline L2.Private_Buildings_Damaged & & & & & -98.86 & & -73.83 \\
\hline Roads_Damaged & & & & & & $-0.00196 * * *$ & $-0.00181 * * *$ \\
\hline L1.Roads_Damaged & & & & & & $-0.00176^{*}$ & -0.00164 \\
\hline L2.Roads_Damaged & & & & & & -0.000181 & 0.000164 \\
\hline POPDEN & -0.0260 & -0.0254 & -0.0260 & -0.0260 & -0.0258 & -0.0257 & -0.0259 \\
\hline GRDPCAP & -0.0129 & -0.0126 & -0.0126 & -0.0123 & -0.0123 & -0.0123 & -0.0125 \\
\hline 2012.year & 0 & 0 & 0 & 0 & 0 & 0 & 0 \\
\hline 2013.year & 0.00456 & 0.00422 & 0.00425 & 0.00417 & 0.00410 & 0.00438 & 0.00435 \\
\hline 2014.year & $0.0549 * * *$ & $0.0546 * * *$ & $0.0546 * * *$ & $0.0545^{* * *}$ & $0.0543 * * *$ & $0.0546^{* * *}$ & $0.0547 * * *$ \\
\hline 2015.year & $0.0407 * * *$ & $0.0403 * * *$ & $0.0401 * * *$ & $0.0400 * * *$ & $0.0399 * * *$ & $0.0402 * * *$ & $0.0402 * * *$ \\
\hline 2016.year & $0.0336 * * *$ & $0.0334 * * *$ & $0.0331 * * *$ & $0.0330 * * *$ & $0.0330 * * *$ & $0.0333 * * *$ & $0.0330 * * *$ \\
\hline 2017.year & $0.0832 * * *$ & $0.0827 * * *$ & $0.0825^{* * *}$ & $0.0826^{* * *}$ & $0.0823^{* * *}$ & $0.0826^{* * *}$ & $0.0827 * * *$ \\
\hline 2018.year & $0.0565^{* * *}$ & $0.0563 * * *$ & $0.0561 * * *$ & $0.0559 * * *$ & $0.0557 * * *$ & $0.0559 * * *$ & $0.0561 * * *$ \\
\hline _cons & $0.553 *$ & $0.545^{*}$ & $0.547^{*}$ & $0.543^{*}$ & $0.541 *$ & $0.542^{*}$ & $0.546^{*}$ \\
\hline$N$ & 3433 & 3433 & 3433 & 3433 & 3433 & 3433 & 3433 \\
\hline$R^{2}$ & 0.108 & 0.108 & 0.108 & 0.108 & 0.108 & 0.107 & 0.109 \\
\hline adj. $R^{2}$ & 0.105 & 0.105 & 0.105 & 0.105 & 0.105 & 0.105 & 0.102 \\
\hline F - stat & 40.41 & 40.93 & 42.66 & 43.55 & 43.23 & 50.19 & 27.10 \\
\hline Prob $>$ F & 0.000 & 0.000 & 0.000 & 0.000 & 0.000 & 0.000 & 0.000 \\
\hline
\end{tabular}

$* * *$ Significant at the level of $1 \%$;* Significant at the level of $5 \% ; *$ Significant at the level of $10 \%$

BS = Budgetary Solvency; POPDEN = Population Density (in natural logged form); GRDPCAP = Gross Regional Domestic Product per Capita (in natural logged form); L1 = One year lag; L2 = Two year lag

Acknowledgment We thank the Indonesian Endowment Fund for Education (LPDP) for funding this research.

Open Access This article is licensed under a Creative Commons Attribution 4.0 International License, which permits use, sharing, adaptation, distribution and reproduction in any medium or format, as long as you give appropriate credit to the original author(s) and the source, provide a link to the Creative Commons licence, and indicate if changes were made. The images or other third party material in this article are included in the article's Creative Commons licence, unless indicated otherwise in a credit line to the material. If material is not included in the article's Creative Commons licence and your intended use is not permitted by statutory regulation or exceeds the permitted use, you will need to obtain permission directly from the copyright holder. To view a copy of this licence, visit http://creativecommons. org/licenses/by/4.0/.

\section{References}

Alam, M., and A. Hoque. 2019. Spending pressure, revenue capacity and financial condit[i]on in municipal organizations: An empirical study. The Journal of Developing Areas 53(1): 243-256. 
Benali, N., M.B. Mbarek, and R. Feki. 2019. Natural disaster, government revenues and expenditures: Evidence from high and middle-income countries. Journal of the Knowledge Economy 10(2): 695-710.

Benson, C., and E.J. Clay. 2004. Understanding the economic and financial impacts of natural disasters. Disaster Risk Management Series no. 4. Washington, DC: World Bank.

Bergholt, D., and P. Lujala. 2012. Climate-related natural disasters, economic growth, and armed civil conflict. Journal of Peace Research 49(1): 147-162.

Bevan, D., and S. Cook. 2015. Public expenditure following disasters. World Bank Policy Research Working Paper no. 7355. https:// doi.org/10.1596/1813-9450-7355. Accessed 9 Sept 2021.

Bisogno, M., B. Cuadrado-Ballesteros, S. Santis, and F. Citro. 2019. Budgetary solvency of Italian local governments: An assessment. International Journal of Public Sector Management 32(2): 122-141.

Botzen, W.J.W., O. Deschenes, and M. Sanders. 2019. The economic impacts of natural disasters: A review of models and empirical studies. Review of Environmental Economics and Policy 13(2): 167-188.

Calkin, D.E., K.M. Gebert, J.G. Jones, and R.P. Neilson. 2005. Forest service large fire area burned and suppression expenditure trends, 1970-2002. Journal of Forestry 103(4): 179-183.

Cermeño, R., and K.B. Grier. 2006. Conditional heteroskedasticity and cross-sectional dependence in panel data: An empirical study of inflation uncertainty in the G7 countries. In Panel data econometrics: Theoritical contributions and empirical applications, ed. B.H. Baltagi, 259-277. Amsterdam: Elsevier.

Chapman, J.I. 2008. State and local fiscal sustainability: The challenges. Public Administration Review 68(1): 115-131.

Chhibber, A., and R. Laajaj. 2008. Disasters, climate change and economic development in Sub-Saharan Africa: Lessons and directions. Journal of African Economies 17((Supplement 2)): ii7-ii49.

Deryugina, T. 2017. The fiscal cost of hurricanes: Disaster aid versus social insurance. American Economic Journal: Economic Policy 9(3): 168-198.

Escaleras, M., and C.A. Register. 2012. Fiscal decentralization and natural hazard risks. Public Choice 151(1-2): 165-183.

Honadle, B.W., J.M. Costa, and B.A. Cigler. 2004. Fiscal health for local governments. Amsterdam: Elsevier.

Ibarraran, M.E., M. Ruth, S. Ahmad, and M. London. 2009. Climate change and natural disasters: Macroeconomic performance and distributional impacts. Environment, Development and Sustainability 11(3): 549-569.

Jimenez, B.S. 2009. Fiscal stress and the allocation of expenditure responsibilities between state and local governments: An exploratory study. State and Local Government Review 41(2): 81-94.

Klomp, J., and K. Valckx. 2014. Natural disasters and economic growth: A meta-analysis. Global Environmental Change 26: 183-195.

Lee, D., H. Zhang, and C. Nguyen. 2018. The economic impact of natural disasters in Pacific island countries: Adaptation and preparedness. IMF Working Papers Vol. 18. Washington, DC:
International Monetary Fund. https://doi.org/10.5089/ 9781484353288.001. Accessed 6 Sept 2020.

Leppänen, S., L. Solanko, and R. Kosonen. 2017. The impact of climate change on regional government expenditures: Evidence from Russia. Environmental and Resource Economics 67(1): 67-92.

Lis, E.M., and C. Nickel. 2010. The impact of extreme weather events on budget balances. International Tax Public Finance 17(4): 378-399.

Medina, L. 2018. Assessing fiscal risks in Bangladesh. Asian Development Review 35(1): 196-222.

Miao, Q., Y. Hou, and M. Abrigo. 2018. Measuring the financial shocks of natural disasters: A panel study of U.S. States. National Tax Journal 71(1): 11-44.

Ministry of Finance. 2018. Disaster risk financing and insurance strategy. Jakarta, Indonesia: Fiscal Policy Agency.

Mochizuki, J., S. Vitoontus, B. Wickramarachchi, S. HochrainerStigler, K. Williges, R. Mechler, and R. Sovann. 2015. Operationalizing iterative risk management under limited information: Fiscal and economic risks due to natural disasters in Cambodia. International Journal of Disaster Risk Science 6(4): 321-334.

Narayan, P.K. 2003. Macroeconomic impact of natural disasters on a small island economy: Evidence from a CGE Model. Applied Economics Letters 10(11): 721-723.

Noy, I., and C. Edmonds. 2019. Increasing fiscal resilience to disasters in the Pacific. Natural Hazards 97(3): 1375-1393.

Noy, I., and A. Nualsri. 2011. Fiscal storms: Public spending and revenues in the aftermath of natural disasters. Environment and Development Economics 16(1): 113-128.

Ouattara, B., E. Strobl, J. Vermeiren, and S. Yearwood. 2018. Fiscal shortage risk and the potential role for tropical storm insurance: Evidence from the Caribbean. Environment and Development Economics 23(6): 702-720.

Panwar, V., and S. Sen. 2019. Economic impact of natural disasters: An empirical re-examination. Margin: The Journal of Applied Economic Research 13(1): 109-139.

Shabnam, N. 2014. Natural disasters and economic growth: A review. International Journal of Disaster Risk Science 5(2): 157-163.

Skidmore, M., and H. Toya. 2013. Natural disaster impacts and fiscal decentralization. Land Economics 89(1): 101-117.

Strulik, H., and T. Trimborn. 2019. Natural disasters and macroeconomic performance. Environmental and Resource Economics 72(4): 1069-1098.

Tang, R., J. Wu, M. Ye, and W. Liu. 2019. Impact of economic development levels and disaster types on the short-term macroeconomic consequences of natural hazard-induced disasters in China. International Journal of Disaster Risk Science 10(3): 371-385.

Unterberger, C. 2017. How flood damages to public infrastructure affect municipal budget indicators. Economics of Disasters and Climate Change 2(1): 5-20.

Wu, J., G. Han, H. Zhou, and N. Li. 2018. Economic development and declining vulnerability to climate-related disasters in China. Environmental Research Letters 13(3): 034013. 